Academic

Journal of

Islamic Studies
Institut Agama Islam Negeri (IAIN) Curup, Indonesia

ISSN 2580-3174, (p); 2580-3190 (e)

volume 6, number 1, 2021 | page: 1-24

DOI: http://doi.org/10.29240/ajis.v6i1.2168

\title{
The Implementation of Hadits on Dzikir and Ihsan: a Living Hadith Study on the Manaqiban Tradition in Majelis Dzikir Al-Khidmah Lampung
}

\author{
Muhamad Nasrudin, Digdo Aji Mukti, \\ Ahmad Nashirudin, Ibnu Akbar Malik \\ Institut Agama Islam Negeri Metro Lampung, Indoneisa \\ idenasrudin@metrouniv.ac.id
}

\begin{abstract}
Al-Khidmah is a council of dzikir in which the congregations consist of various educational, economic, and social backgrounds. Uniquely, in the council, there are people who have criminal backgrounds such as drug addicts and thugs. In its development, these people experienced a change in character towards ihsan. This change is suspected to be the impact of their participation in Majelis Dzikir Al-Khidmah of dzikir. This paper examines the living hadith about dzikir and ihsan in Al-Khidmah and it's role in shaping the character of its congregations towards ihsan. This paper was a field research in Simbarwaringin, Trimurjo sub-district, Central Lampung. This was a qualitative descriptive paper that provides a description of the living hadith and the formation of ihsan characters in Al-Khidmah Lampung. This paper was conducted by using participation method with the symbolic interaction method. The results concluded that Al-Khidmah revived the values of hadith about ihsan in three forms of tradition: practice, oral, and written. The character of the ihsan is measured by using the parameters of the asas al khomsa contained in the interaction model, the relation model, and the ritual dzikir of manaqib. This paper adds the treasure of the hadith study about the practice of hadith to form the character of ihsan through tarekat.
\end{abstract}

Keywords: living hadith; hadith on dzikir; hadith on ihsan; ihsan character; Majelis Dzikir al-Khidmah

\section{Introduction}

Simbarwaringin is a village which is in the capital of Trimurjo sub-district, Central Lampung. The total area of Simbarwaringin is 7.16 $\mathrm{km}^{2}$ with a population of 56,165 people. From total population of Simbarwaringin, 6,141 ere are Muslims and 24 people are Catholics. The livelihoods of the population range from farmers, teachers, police, doctors, and others.

Simbarwaringin is classified as rural and was formed in 1972 as a result of the division of Kaliwungu village. Administratively, this village 
is under Lampung Tengah district, but geographically the village is 30 $\mathrm{km}$ from the district center on Gunung Sugih. On the other hand, this village is close to Metro city, only about $9 \mathrm{~km}^{1}$. In other words, this village is experiencing a cultural shock problem, where the population is experiencing a transition from a rural community to an urban community.

The heterogeneity of the Simbarwaringin community is in line with the complexity of the problems in it. Like urban communities in general, crime is one of the problems in Simbarwaringin village. Various cases have occurred in Simbarwaringin such as theft, robbery, drug trafficking and gangsters. In many cases, these crimes are the way people face their economic problems. For example, December 26, 2019, a resident of Simbarwaringin with the initials AM was arrested by the Lampung Tengah Police Narcotics Detective Unit for drug abuse charges. $^{2}$

However, not all people in Simbarwaringin use criminal means to solve their problems. On the other hand, some people also choose a more moderate path, such as returning to the path of religion. The emergence of prayer councils, recitation congregations, and dzikir assemblies have become media for the community to prepare individuals who are more resilient in facing world problems. AlKhidmah is one of the dzikir assemblies in Simbarwaringin. Unlike the Jamiyyah Tariqah in general which is only followed by students, the Majelis Dzikir Al-Khidmah is more open to the congregations. Regardless of age, sex, occupation, or education, anyone can join this assembly. The congregations also consist of various different backgrounds ranging from students, the general public, students, academics, and others.

What interesting is that among the congregations, there are some people who previously had criminal records. The participation of these people in the Majelis Dzikir Al-Khidmah apparently had an impact on their character and behavior. There was a significant change between before following and after joining the assembly. This difference can be

1 Sidik Purnomo, Trimurjo Dalam Angka (2019) (Lampung Tengah: Badan Pusat Statistik Kabupaten Lampung Tengah, 2019).

2 Penulis Redaksi Runnews, "Ketahuan Menyembunyikan Sabu, Seorang Pemuda Diamankan Sat Narkoba Polres Lampung Tengah," News, Runnews Lampung Update (blog), Desember 2019, https://www.runnews.co.id/ketahuanmenyembunyikan-sabu-seorang-pemuda-diamankan-sat-narkoba-polres-lampungtengah/. 
seen from the way they speak, emotional control, and attitude in dealing with problems.

The author then made observations on nine congregations consisting of former thugs, thugs, robbers, and drug dealers. The preliminary findings indicate that there are changes in their character in terms of several aspects, which can be seen in the table as follows: ${ }^{3}$

\begin{tabular}{|l|l|l|l|}
\hline No & Aspect & Before & After \\
\hline 1 & Mindset & $\begin{array}{l}\text { His thoughts are } \\
\text { only for worldly } \\
\text { pleasures. }\end{array}$ & $\begin{array}{l}\text { He has begun to } \\
\text { mature in thinking } \\
\text { and balancing } \\
\text { between the world } \\
\text { and the hereafter. }\end{array}$ \\
\hline 2 & Profession & $\begin{array}{l}\text { Stealing, robbing, } \\
\text { thuggery, drug } \\
\text { trafficking, and } \\
\text { fraud. }\end{array}$ & $\begin{array}{l}\text { Starting looking for a } \\
\text { halal job (farmer, } \\
\text { trader, entrepreneur) }\end{array}$ \\
\hline 3 & Speaking style & $\begin{array}{l}\text { Speaking with loud } \\
\text { intonation }\end{array}$ & $\begin{array}{l}\text { Being calmer in } \\
\text { speaking and using } \\
\text { polite Javanese } \\
\text { (Kromo Inggil) }\end{array}$ \\
\hline 4 & worship & $\begin{array}{l}\text { Never praying } \\
\text { manaqib }\end{array}$ & $\begin{array}{l}\text { Already started } \\
\text { praying 5 times a day }\end{array}$ \\
\hline 5 & Hobby & $\begin{array}{l}\text { Liked to hang out } \\
\text { with friends and } \\
\text { commit immorality } \\
\text { (drinking alcohol, } \\
\text { drugs, gambling) }\end{array}$ & $\begin{array}{l}\text { Likes to follow } \\
\text { religious traditions } \\
\text { such as recitation, } \\
\text { tahlilan, yasinan, and } \\
\text { manaqib. }\end{array}$ \\
\hline 6 & $\begin{array}{l}\text { Attitude when } \\
\text { followed bored, and did not }\end{array}$ & $\begin{array}{l}\text { When he first } \\
\text { fhanting of } \text { dzikir until } \\
\text { feeling sad and crying. }\end{array}$ \\
\hline
\end{tabular}

3 Observation on SW, ND, MK, GT, DN, RH, AB, EK, MS pada tanggal 1-2 Februari 2020 di Majelis Dzikir Al-Khidmah. 


\begin{tabular}{|l|l|l|l|}
\hline & & absorb. & \\
\hline 7 & Manaqib priority & $\begin{array}{l}\text { Doing Manaqib } \\
\text { when there is no } \\
\text { agenda }\end{array}$ & $\begin{array}{l}\text { Doing Manaqib } \\
\text { routinely at } \\
\text { Simbarwaringin }\end{array}$ \\
\hline
\end{tabular}

Borrowing the theory of asasul khomsah that was coined by the Mahasiswa Ahli Thariqoh Al-Mu'tabaroh An-Nahdhiyah (MATAN), the organization under the auspices of Jam'iyyah Ahlit Thoriqoh AlMu'tabaroh An-Nahdliyyah (JATMAN NU), the changes experienced by the congregations were the representation of the five principles of the five souls (lima asas panca jiwa). ${ }^{4}$ The five principles are; First, tafaqquh fiddin (mastery of religious and worldly sciences) is reflected in the mindset of the congregations who begin to balance the interests of the world and the hereafter. Second, iltizamut tho'at (obeying Allah, Rasulullah saw, ulil amri, and murshid), which is a change in the aspect of carrying out his worship which is increasingly perfect and complete.

Third, tashfiyat al-qulub wa tazkiyat al-nafsi (cleansing the heart and purifying oneself), seen from the congregations' speech gestures and their easily controlled emotions. Fourth, hifdz al-aurad wa al-adzkar (always intending to worship Allah SWT.), The congregations always take time to follow manaqib as an activity to get closer to Allah SWT. Fifth, khidmah lil-ummah (devotion to fellow humans, nation and state as a form of devotion to God Almighty.) The congregation uses religious traditions as a medium for interaction with islamic brotherhood (ukhuwah islamiyah).

In the conception formulated by MATAN, the asasul khomsah is an operational concept to describe the personal ihsan that occurs in the congregations. Ihsan in the sense of noble morals or education towards noble morals is the highest peak of one's religion. The term ihsan itself is mentioned in the hadith of the Prophet when someone asks about ihsan, "You should worship Allah as if you saw Him", then really he saw you."

Broadly speaking, the term living hadith can be defined as a scientific study or research on various social events related to the

4 Blog Author, "Asasul Khomsah MATAN," Religi, MATAN Hadiningrat (blog), 2020, https://matanhadiningrat.com/asasul-khomsah-matan/. 
presence or existence of hadith in a particular Muslim community. ${ }^{5}$ The living hadith values ihsan in the assembly of al-Khidmah Lampung is a phenomenon of living hadith. The actualization of hadith values about ihsan in the Al-Khidmah assembly aims to shape the character and personality of the ihsan of the congregation. Meanwhile dzikir and manaqib become instruments in order to achieve this goal. The packaging of dzikir and manaqib in a distinctive ritual affects the peace of mind for the congregation and leads to the formation of the character of ihsan.

Dzikir is a form of worship that not only benefits from the dimensions of the vertical relationship between God and a servant, but also has practical benefits both physically and spiritually. According to research conducted by Ayu Efita Sari, there is a significant influence between $d z i k r$ on mental calm in Majlisul Dzakirin Kamulan. This is evident from the large percentage of mental tranquility of $6.5 \%$, which is influenced by environmental factors and the rules applied in Majlisul Dzakirin Kamulan. ${ }^{6}$

Furthermore, dzikr also has an effect on changes in the social behavior of the congregation in dzikir assemblies. Muhammad Yusuf in his thesis concluded that the behavior changes that occurred in the congregation of the Tarekat Qadriyah wa Naqsabandiyah Malang City could be seen from the aspects of lifestyle, being helpful, increasing friendship, and amar ma'ruf nahi munkar. This change is due to the success of the tarekat teaching which is able to guide and direct the positive behavior of its congregation according to Islamic teachings, both in terms of individual changes and socio-religious behavior in the midst of society. ${ }^{7}$

As a model for the study of hadith, living hadith has been widely practiced in various objects, from religious traditions to pop culture

5 Adrika Fithrotul Aini, "Living Hadis Dalam Tradisi Malam Kamis Majelis Shalawat Diba' Bil-Mustofa," Ar-Raniry: International Journal of Islamic Studies 2, no. 1 (2014): 227.

${ }^{6}$ Ayu Efita Sari, "Pengaruh Pengamalan Dzikir Terhadap Ketenangan Jiwa Di Majlisul Dzakirin Kamulan Durenan Trenggalek" (Skripsi, Jawa Timur, Institut Agama Islam Negeri Tulungagung, 2015), 84.

7 Muhammad Yusuf, "Tarekat Dan Perubahan Perilaku Sosial Keagamaan Pada Jama'ah Tarekat Qadriyah Wa Naqsabandiyah Di Kota Malang: Perspektif Tindakan Sosial Max Weber" (Tesis, Malang, Universitas Islam Negeri Maulana Malik Ibrahim, 2018), 67. 
products. ${ }^{8}$ In the study of religious traditions, several objects that have been studied include the maulid tradition ${ }^{9}$, the alms tradition ${ }^{10}$, the dhuha prayer tradition ${ }^{11}$, and so on. Meanwhile, in the realm of popular culture, for example, Nurmansyah has studied living hadith in films. ${ }^{12}$

Then in the context of al-Khidmah as a research subject, the research that has been carried out is about the progress and its impact on the formation of a sakinah family ${ }^{13}$, strengthening patient attitudes ${ }^{14}$, increasing spiritual intelligence ${ }^{15}$, tolerance and social care ${ }^{16}$, and the ability to exercise self-control. ${ }^{17}$ Research on the role of Majelis alKhidmah in shaping the character of ihsan has not been done so much.

Meanwhile, research and publications on dzikir and its role in individual life are more oriented towards the formation of identity and meaning of life ${ }^{18}$; as a complement to thinking to shaping the character

8 Saifuddin Zuhri Qudsy, "LIVING HADIS: GENEALOGI, TEORI, DAN APLIKASI," Jurnal Living Hadis 1, no. 1 (May 6, 2016): 177-96, https://doi.org/10.14421/livinghadis.2016.1073.

${ }^{9}$ Dewi Fatonah, "Tradisi Maulid Arba'in Di Kampung Arab Al-Munawwar Palembang," Jurnal Living Hadis 5, no. 1 (2020).

10 Muhammad Rafi, "Living Hadis: Tradisi Sedekah Nasi Bungkus Hari Jum'at Oleh Komunitas Sijum Amuntai," Jurnal Living Hadis IV, no. 1 (Mei 2019).

11 Nurul Afifah, "Salat Duha sebagai Budaya Populer dalam Pemaknaan Anggota Mejelis Dhuha Bantul," RELIGIA, February 19, 2018, 160-73, https://doi.org/10.28918/religia.v20i2.927.

12 Ihsan Nurmansyah, "Resepsi Dan Transmisi Pengetahuan Dalam Film Papi Dan Kacung Episode 8-11: Sebuah Kajian Living Hadis," AL-Quds: Jurnal Studi Al-Qur'an Dan Hadis 3, no. 2 (2019).

${ }^{13}$ Khoirul Anam, "Keluarga Sakinah Dan Dzikir (Studi Atas Peran Majelis Dzikir Al-Khidmah Dalam Pembentukan Keluarga Sakinah Di Kabupaten Semarang)” (Skripsi, Jawa Tengah, Institut Agama Islam Negeri Salatiga, 2015).

14 Nur Ikhsan Ari Wibowo, "Hubungan Keaktifan Mengikuti Majelis Dzikir Dengan Sikap Sabar Jama'ah Al Khidmah Kecamatan Tingkir Kota Salatiga Tahun 2013" (Thesis, IAIN SALATIGA, 2013), http://e-repository.perpus.iainsalatiga.ac.id/7089/.

15 Lailatul Janah, "Peran Majelis Dzikir Al Khidmah Dalam Mengembangkan Kecerdasan Spiritual (Studi Pada Jamaah Majelis Dzikir Mahasiswa Al Khidmah Kota Salatiga 2016)" (PhD Thesis, IAIN SALATIGA, 2017).

16 Nadzifah Nuriyatun, "Implikasi Kegiatan Majelis Al-Khidmah Dalam Membentuk Karakter Toleransi Dan Peduli Sosial Pada Jama'ah Remaja Di Kecamatan Sayung Kabupaten Demak" (Thesis, Universitas Wahid Hasyim, 2020), http://eprints.unwahas.ac.id/2539/.

${ }^{17}$ Ali Muntaha, "Korelasi Antara Intensitas Mengikuti Majelis Dzikir Khushushy Al-Khotmy Dengan Kontrol Diri (Self Control) Pada Jama'ah Al Khidmah Kabupaten Semarang." (Thesis, Salatiga, IAIN Salatiga, 2019), http://erepository.perpus.iainsalatiga.ac.id/5944/.

18 Yedi Supriadi, "Dzikir, Spiritualitas Dan Intuisi: Studi Tentang Pembentukan Jati Diri Di Majelis Dzikir Rijalullah Majalengka," Irsyad : Jurnal Bimbingan, Penyuluhan, 
of students in school ${ }^{19}$; character of adolescents ${ }^{20}$, the meaning of student life in university ${ }^{21}$; and building character of society ${ }^{22}$. Research that examines the dzikir and the formation of the character of ihsan as not yet widely studied.

In contrast to the various research and publications above, this article explores the role of dzikir assemblies in shaping the character of their congregations from the point of view of the hadiths used as the basis for these dzikir assemblies. The object in this article is the Majelis Dzikir Al-Khidmah in Lampung. This paper examines the role of the Majelis Dzikir Al-Khidmah in Lampung in constructing the character of the congregation in it, thus forming the character of ihsan. Before that, this paper will first examine how al-Khidmah lived the values of the Prophet's hadith in shaping the character and personality of his congregation.

This paper seeks to answer of how hadith on dzikir and ihsan was living in Majelis Dzikir al-Khidmah? On this fundament of study, this work describes how the Majelis Dzikir Al-Khidmah creates the formation of ihsan characters within it's congregations. Primary data were obtained through observation and interviews with the coordinators, congregations, and murshid Majelis Dzikir al-Khidmah in Lampung. Meanwhile, secondary data is obtained from books, journal articles, theses, and internet sources. The data were collected using the participatory method and analyzed using the symbolic interaction

Konseling, Dan Psikoterapi Islam 8, no. 3 (September 30, 2020): 231-50, https://doi.org/10.15575/irsyad.v8i3.2000.

19 Muhammad Anas Maarif and Muhammad Husnur Rofiq, "Dzikir Dan Fikir Sebagai Konsep Pendidikan Karakter: Telaah Pemikiran KH. Munawwar Kholil AlJawi," Tadrib 5, no. 1 (2019): 1-20, https://doi.org/10.19109/tadrib.v5i1.3066.

20 Adni, "Pola Pembinaan Majelis Taklim Dzikir Nur Al-Mu'min Dalam Pembentukan Karakter Remaja Di Kelurahan Parit Tokaya Kecamatan Pontianak Selatan Kota Pontianak," SOCIOLOGIQUE - Jurnal Sosiologi 3, no. 3 (December 17, 2015), http://fisipuntan.org/jurnal/index.php/sociologique/article/view/1240; A Maturidi, "Peranan Majelis Dzikir Dalam Pembentukkan Karakter Remaja," Jurnal Dirosah Islamiyah 1, no. 1 (2019): 79-92.

21 Wahyu Kurniawan and Rahma Widyana, "Pengaruh Pelatihan Dzikir terhadap Peningkatan Kebermaknaan Hidup pada Mahasiswa," JIP (Jurnal Intervensi Psikologi) 5, no. 2 (December 31, 2013): 217-38, https://doi.org/10.20885/intervensipsikologi.vol5.iss2.art5.

22 M. Yusuf Asry, "Sosialisasi Zikir Melalui Komunikasi dari Mulut ke Mulut dalam Membangun Karakter Masyarakat oleh Majelis Dzikir dan Shalawatan Al Mutathahhirien," WACANA: Jurnal Ilmiah Ilmu Komunikasi 17, no. 1 (July 28, 2018): 125-34, https://doi.org/10.32509/wacana.v17i1.517. 
method. Data interpretation using symbolic theory was carried out on interviewing data obtained from the congregations of the Majelis Dzikir Al-Khidmah. Observations were made on speech gestures, facial expressions, and the behavior of the congregations while following the manaqib ritual.

\section{Discussion}

\section{Hadith on Dzikr and Ihsan}

Hundreds of hadith allude to dhikir. The most popular is the hadith regarding the recognition that Allah is in accordance with the allegations of his servant and when a servant dhikir (remembering or chanting) Allah, then Allah will remember and mention the servant. This hadith is narrated in Bukhari 740523; Muslim 267524; Ibn Majah 382225; Tirmizi 360326; and Riyad as-Salihin 143527. The following hadith in popular version is below:

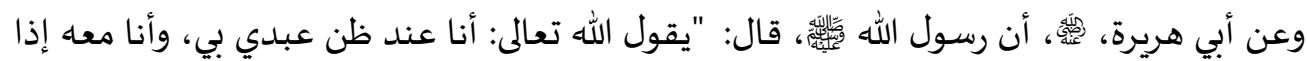

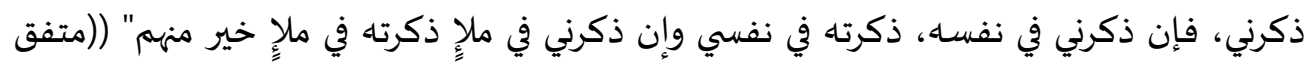
عليه()).

"The Messenger of Allah said, "Allah the Exalted says: 'I am as my slave expects me to be, and I am with him when he remembers Me. If he remembers Me inwardly, I will remember him inwardly, and if he remembers Me in an assembly, I will remember him in a better assembly (i.e., in the assembly of angels)."

Many popular hadith are sahih and mutawatir that discuss on ihsan. The most popular of these is the hadith about the Jibril teaching the Prophet Muhammad in a forum with sahabat. This hadith is narrated by many hadith books with different word but the content is the same. This hadith is listed in Bukhari 50 and 4777; Muslim 8 and 10; Imam Nasai 499028; Ibn Majah vol. 1:63 and 6429; Ahmad 184, 367, 36830;

23 Imam Muhammad bin Ismail al-Bukhari, Sahih Bukhari (Beirut: Dar Ibn Katsir, 2018).

${ }^{24}$ Imam Muslim bin al-Hajjaj al-Qusyairy an-Naisabury, Sahih Muslim (Beirut: Dar al-Kitab al-Ilmiyyah, 2010).

25 Imam Ibnu Majah, Sunan Ibnu Majah (Bait Afkar Dauliyah, 2006).

${ }^{26}$ Imam Muhammad bin Isa at-Tirmidzi, Sunan Tirmizi (Dar al-Ghad al-Jadid, 2015).

28 Imam an-Nasai, Sunan An-Nasai (Dar al-Alamiyah li an-Nasyr wa at-Tajlid, 2018).

${ }^{29}$ Ibnu Majah, Sunan Ibnu Majah. 
Arbain Nawawi 231, Riyadhus Salihin 60; Tirmizi 2610, Imam Nasai 4991; and Abu Dawud 4695. This hadith in Bukhari's narration is below:

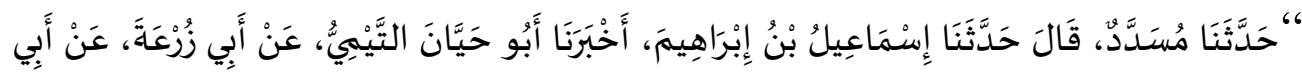

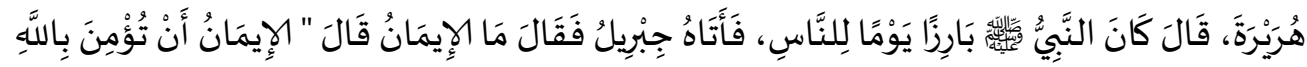

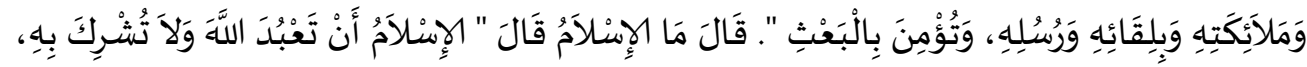

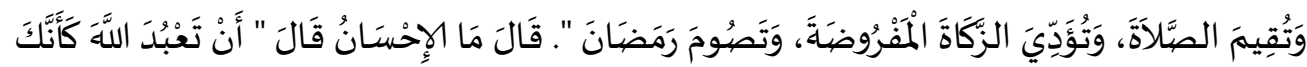

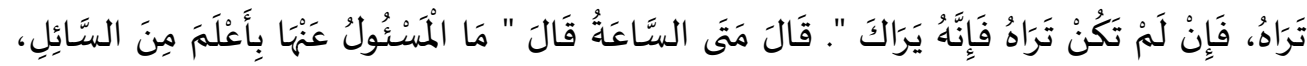

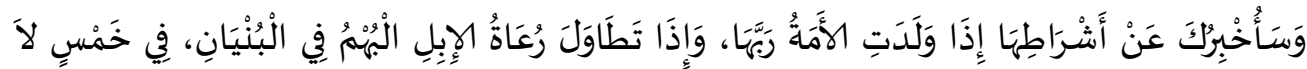

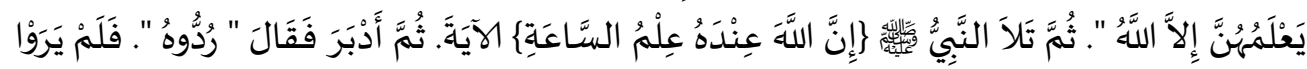

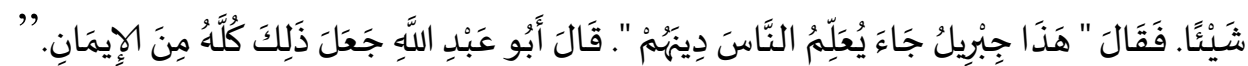

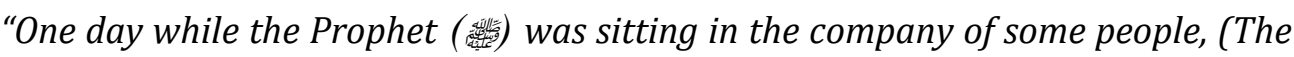
angel) Gabriel came and asked, "What is faith?" Allah's Messenger (踇) replied, 'Faith is to believe in Allah, His angels, (the) meeting with Him, His Apostles, and to believe in Resurrection." Then he further asked, "What is Islam?" Allah's Messenger (証) replied, "To worship Allah Alone and none else, to offer prayers perfectly to pay the compulsory charity (Zakat) and to observe fasts during the month of Ramadan." Then he further asked, "What is Ihsan (perfection)?" Allah's Messenger (政) replied, "To worship Allah as if you see Him, and if you cannot achieve this state of devotion then you must consider that He is looking at you." Then he further asked, "When will the Hour be established?" Allah's Messenger

(政) replied, "The answerer has no better knowledge than the questioner. But I will inform you about its portents."

\section{Profile of Majelis Dzikir Al-Khidmah Lampung}

Al-Khidmah is a dzikir assembly founded by KH. Ahmad Asrori alIshaqi. He is a prominent Sufi cleric and caretaker of the Al-Fitrah Islamic Boarding School in Surabaya. Long before the founding of AlKhidmah, in the 1980s KH. Ahmad Asrori al-Ishaqi often mingled with youths in Gresik. His preaching begins by inviting young men who love to do immorality to be guided slowly to the right path. So that the association was given the name orong-orong (an animal like a cricket) or a small animal that appears in the dark looking for light at night and surrounds it. The philosophy of this name is that young people whose

\footnotetext{
${ }^{30}$ Imam Ahmad bin Hanbal, Musnad Imam Ahmad (Bait Afkar Dauliyah, 2000).

31 Yahya bin Syaraf an-Nawawi, Al-Arbain an-Nawawi (Damaskus: Dar al-Fath, 2009).
} 
lives are initially dark are full of immoral acts and sins that are guided to a life of the light of truth by ahklak al-karîmah.

The name Al-Khidmah itself originally emerged from the habit of Al-Fitrah students who wrote the word "Al-Khidmah" (servant) in the lower right corner of the assembly invitation letter for congregations. This habit makes the residents of the neighborhood around the lodge call the assembly "Al-Khidmah". So that the name is until now known as the name Al Khidmah, a dzikir assembly led by Kyai Ahmad Asrori. ${ }^{32}$

Khidmah, literally means serving, cuddling, accompanied by a sense of andhap ashor, tawadlu', polite and sincere. Khidmah, according to H. Hasanudin, Chairman of al-Khidmah Indonesia, is not only sincere, but also professional. According to $\mathrm{H}$. Hasanudin, what is meant by congregation al-Khidmah is an association of assemblies or organizations that guide people to get closer to Allah Almighty through practices such as collective prayer assemblies, manaqib assemblies from scholars. As for the formation of the al-Khidmah congregations to create a righteous and righteous generation, physically and mentally prosperous, who are good at being grateful, can please their family, their parents, their teachers to the Prophet Muhammad, according to the instructions of the Koran and al-Hadith. as well as moral guidance from the Islamic scholars. ${ }^{33}$

Along with its development, the congregations of Al-Khidmah increased in number, so that a community that could organize congregations in large numbers was needed. So a forum called "Jamaah Al Khidmah" was formed. This organization was declared on December 25, 2005 in Semarang, Central Java, with its main activities being the Dzikir Council, the Khotmil al-Qur'an, Maulid, and Manaqib Council as well as sending prayers to parents and teachers, and others.

Al-Khidmah organization has been officially registered at the Ministry of Law and Human Rights of the Republic of Indonesia with deed number AHU 25 AH 01.06 in 2011. Al-Khidmah has branches in various provinces in Indonesia, even abroad such as in Malaysia, Singapore and Brunei Darussalam. The rationale for the birth of AlKhidmah includes: the more difficult and difficult it is to hold fast to aqidah, belief, and the true, upright and upright religious journey; and

32 Anam, "Keluarga Sakinah Dan Dzikir (Studi Atas Peran Majelis Dzikir AlKhidmah Dalam Pembentukan Keluarga Sakinah Di Kabupaten Semarang).”

33 Umar Faruq, "Al-Khidmah Kampus UIN Sunan Kalijaga" (Skripsi, Yogyakarta, Universitas Islam Negeri Sunan Kalijaga, 2016). 
the reduced attitude of loving and respecting others, due to less or no shame.

One of the Al-Khidmah branches is the Lampung Province branch. Jamaah Al-Khidmah first entered Lampung Province in 2005. However, the management of Al-Khidmah in Lampung province was only formed in 2014 at the Islamic Boarding School Miftahurrohmah Pesisir Barat under KH. Ahmad Yasin. Al-Khidmah Lampung Province is scattered in several points including Gula Putih Mataram (GPM), Lampung Tengah led by KH. Abrori Akwan, a student from KH. Ahmad Asrori Al-Ishaqi; at the Darul Falah Mesuji Islamic Boarding School led by KH. Ahmad; and in Simbarwaringin, Central Lampung under the leadership of Kyai Mukhlasin, who was then taken to the Riyadhatul Qur'an Islamic Boarding School, Metro City.

Majelis al-Khidmah has a distinctive characteristic in carrying out its amaliyah. This assembly combines manaqib, dzikir and shalawat. Therefore, this assembly has a different style and impression for each of its congregations. The Jamaah of Majelis al-Khidmah itself is not only a group of kiai (ulama). Various groups of people, from criminals to officials join together to do dzikir, read manaqib, and together knit longing for the Prophet by reading prayer.

Al-Khidmah also facilitates each of its congregation who wants to send prayers to his relatives who have died. In addition, Al-Khidmah also commemorates and sends prayers on the day of the death of important figures such as Syekh Abdul Qodir Jailani and KH. Ahmad Asrory Al-Ishaqi who is also a murshid of the Qadiriyah wa Naqsabandiyah. ${ }^{34}$ This activity, called haul, is usually carried out on a national scale attended by branches from various provinces.

\section{Living Hadith Phenomenon in Majelis Dzikir Al-Khidmah Lampung}

Al-Khidmah is one of the dzikir assemblies which acts as an agent of living hadiths in shaping the character of its congregation. Personal achievements and characteristics of ihsan in this case are contextualized in a tarekat organization using dzikir and manaqib as the main instruments. In general, the practice of hadith in the dzikir Manaqib AlKhidmah tradition consists of three forms, namely the practice, oral, and written traditions. The following is an explanation of the living hadith in the al-Khidmah dzikir assembly in Lampung.

34 Saiful Hadi, Wawancara tentang Sejarah Majelis Dzikir Al-Khidmah Lampung, January 8, 2019. 
First, living hadith in the practice tradition. As previously explained that tarekat and Sufism can act as intermediaries to achieve the personality and character of ihsan. Dzikir and manaqib are important instruments for honing the mind of the congregation in order to achieve personal ihsan. The dzikir and manaqib services in the Majelis Dzikir AlKhidmah are packaged in a certain unique and distinctive rite. The rite referred to here means several activities that are "sacred", and have certain procedures (solemn ceremonies and processions), and require joint involvement between students and murshids.

Al-Khidmah packs dzikir into religious rituals in congregation with distinctive chants so as to have an impact on mental tranquility for the congregation. Although Al-Khidmah is not limited to one type of tarekat, the dominant one used is the Qadiriyah wa Naqsabandiyah Tarekat. The procedures before doing dzikir include repenting to Allah for all the sins he has committed, bathing and ablution, keeping silent or calming down to concentrate the mind, intending to ask Allah for help through the teacher, determined to ask the Prophet Muhammad's help through the teacher.

The procedures for dzikir include being in a holy place, getting used to humble oneself in dzikir, wearing clean clothes and wearing fragrances (preferably white clothes), choosing a place that is dim / not dark, controlling views and thoughts, being honest in dzikir, and sincere, read the dzikir well.

While in the assembly, the congregation is not allowed to carry out activities other than dzikir such as chatting with each other, using communication tools (cellphones), smoking, and making body movements that are not part of the dzikir ritual series. It aims to maintain calm and solemnity during the implementation of dzikir. By getting used to focusing on the presence of the Khaliq, it will also affect the person who is always introspective. ${ }^{35}$

Second, living hadith in the oral tradition. The phenomenon of living hadith in the form of an oral tradition in Majelis al-Khidmah is found in his dzikir practice. Texts of dzikir in Al-Khidmah include tahlil, tahmid, tasbih, and takbir, each of which is read 313 times. Apart from text dzikir, there are other text which are practiced in the form of an oral tradition.

35 Mukhlasin, Wawancara tentang Majelis dzikir dan Tarekat Al-Khidmah Lampung, January 7, 2020. 
It is true that there is no hadith that is explicit about the number of wirid, except for the dzikir that is done after the prayer that has been determined by the Prophet. Regarding this matter, Murshid al-Khidmah Lampung, Abah Mukhlasin explained that the determination of the number of a wirid does not have to be based solely on hadith, but can also be determined through inspired guidance obtained by righteous servants of God. He quoted a history in a book entitled Jila 'al-Afham written by Ibn Qayyim al-Jauziyah as follows:

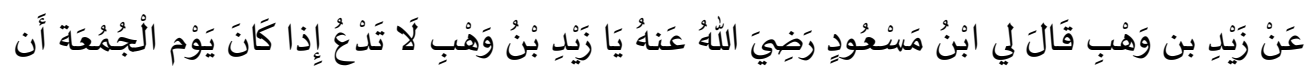

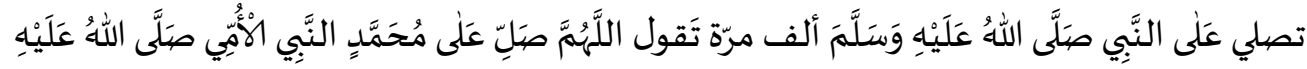
وَسَلَّمَ

"From Zaid bin Wahb, the friend of Ibn Mas'ud said to me: O Zaid, if you do not leave Friday reading prayers on the Prophet 1000 times, say Allahumma salli 'ala Muhammad an-Nabiyyi al-ummiyyi sallallahu alaihi wasallam."

Through this narration, Abah Mukhlasin concluded that the determination of the number of wirid numbers could be determined by the righteous servant of Allah and happened immediately and did not contradict the law. Even this also happened in the time of the sahabat.

Dzikir is worship in order to achieve a ihsan person. Dzikir is also a manifestation of the tazkiyatun nafs (cleaning of soul) by means of the presence of the heart in chanting Allah's name, namely calling it in oral and presenting it in the heart. With a pure heart, it will reflect the behavior and character of ihsan in a person. ${ }^{36}$

Third, living hadith in the writing tradition. The value of the hadith in the form of a written tradition that lives in Al-Khidmah is manifested in the logo of the assembly. In the Al-Khidmah logo, there is a three-star symbol that symbolizes efforts to strengthen and perfect AlIslam, Al-Iman and Al-Ihsan. This meaning describes Al-Khidmah's goal to create a true Islam (kaffah) for its worshipers.

The Majelis Dzikir Al-Khidmah has a book of manaqib compiled by KH. Ahmad Asrory Al-Ishaqy. Living hadiths in the form of written traditions are also found in the manaqib book. The book contains readings in rituals, such as dzikir sentences, Al-Qur'an verses, prayers for the Prophet, management texts, Asmaul Husna and so on. Regarding the hadith which is used as a basis, Saiful Hadi or commonly called Gus Ipul explains as follows:

${ }^{36}$ Mukhlasin. 
"The compilation of the manaqib book itself has basically been exemplified by previous scholars. An example is Imam Ahmad bin Hanbal in his book entitled Al-Musnad, in which there is a chapter of Manaqib Asy-Syamiyin (the history of the pious people of Syam). The arrangement of the book of the manaqib is in the framework of ittiba 'in order to follow what has been explained in the Al-Qur'an, such as the history of the people both in surah Maryam and Luqman. So in general, the values contained in the argument are the basis for manaqib. In particular it is also the foundation in Al-Khidmah."37

The book manaqib Al-Khidmah tells the life of Sheikh Abdul Qadir al-Jailani. The book explains the scriptures, births, spiritual journeys, karamah and advice including orders to always maintain ablution, always draw closer to Allah Most High, practice 99 Asmaul Husna, love the poor, always be grateful in any circumstances, always be patient, always be careful in associating with people. The book is a form of ittiba (following) 'to the previous scholars and pious as someone who has reached an ihsan person.

The life of these hadith values is a riyadhoh to hone the quality of ihsan congregation. The practice of the hadith about ihsan is written in a practice to train the soul and lust in order to fight against bad tendencies. Thus, the person of the ihsan is not only within the scope of the assembly, but will also be accustomed to being applied in the surrounding community.

\section{Jamaah Al-Khidmah understanding of the Hadith about Ihsan}

In the aspect of understanding the hadiths about Islam-ImanIhsan, the congregations do not memorize and understand in detail. However, from the aspect of experience and the rites carried out by the congregations, it refers to the formation of ihsan's character. In an interview with one of Al-Khidmah's congregation, the congregation could not explain the hadith but the congregation could explain the verses of the Koran such as surah ar-Ra'du verse 28, and the sentence "afhloludz dzikri, fa'lam annahu" (the best dzikr, that is) before the recitation tahlil. This indicates that the congregation actually understands the virtue of dzikir, but it is limited to the verses of the AlQur'an or familiar sentences. ${ }^{38}$

\footnotetext{
${ }^{37}$ Hadi, Wawancara tentang Sejarah Majelis Dzikir Al-Khidmah Lampung.

${ }^{38}$ Jama'ah Al-Khidmah, Wawancara kepada Jama'ah tentang Dzikir Manaqib Al-Khidmah, January 30, 2020.
} 
The object of dzikir which is mentioned by the congregation is one of the rites which becomes a tool to reach the degree of ihsan. This dzikir has a significant influence in character building. In solving the problems of daily life before participating in the manaqib dzikir activities, the congregation is often unable to control their emotions, then says harsh or dirty words. After participating in this activity, his emotions are more controlled and there is a separate message to prevent these things. In addition, the intensity of the recitation of dzikir and prayers in daily life increases, both after prayer and at certain times, for example after congregational prayers. Isyarah described by the congregation is a manifestation of a piece of the Prophet's hadith which describes ihsan, which means "Even if you don't see Him, in fact He sees you".

Apart from that, in this dzikir manaqib activity, it was not uncommon for the congregation to cry in response to the atmosphere that was built during this activity, both during dzikir and prayer led by murshid. Responding this phenomenon, the writer uses symbolic interaction theory, the concept of The Definition of the situation found by Wiliam Isac Thomas (1968) in Hendariningrum (2009). In this concept, it is explained that human interaction is built in the form of a response to an external stimulus which is preceded by a process of interpretation and certain considerations, which in turn give meaning to the stimulus it receives. ${ }^{39}$

This is in line with the phenomenon outside the dzikir manaqib ritual, namely murshid guidance to congregations who have a criminal background who eventually return to the right path. The murshid stimulation in the form of spiritual guidance was then responded to by the congregation who previously had a criminal background by returning to the right path. The individual stimulation does not immediately accept it, but it takes a long process and interpretation according to the concept of the definition of the situation.

In symbolic interaction theory, this is included in the premise of an individual responding, including physical and social objects that refer to the meaning contained in the component. ${ }^{40}$ First, the all-white clothes that have become typical of the al-Khidmah dzikir assembly, whether

39 Nina Siti Salmaniah Siregar, "Kajian Tentang Interaksionisme Simbolik," Jurnal Ilmu Sosial 4, no. 2 (Oktober 2011): 106.

40 Dadi Ahmadi, "Interaksi Simbolik: Suatu Pengantar," Mediator 9, no. 302 (Desember 2008): 310. 
worn by congregations or murshids. This has a philosophy that white clothes are Sunnaturrasul so they will bring out their own light, besides that white clothes are also the clothes of pious people. White clothes also symbolize the shroud, the sheet of cloth to be worn when the world dies. Second, the use of buhur during the dzikir manaqib ritual which has a philosophy that fragrance is also a sunaturrasul which can also support solemnity during dzikir. The third is the use of jasmine flowers that are scattered in Al-Khidmah decorations which have the philosophy that the fragrant smell of fresh jasmine can provide positive energy. ${ }^{41}$

\section{Ihsan Character Building}

Amaliyah Al-Khidmah apart from carrying out worship to Allah is also a medium for shaping the character of the congregations in it. The person with character in question is the ihsan person. This character is reflected in their behavior while in the dzikir assembly, such as their ta'ziman towards murshids, being absorbed in dzikir, humorous, polite in speaking, especially to older people, and smiling. This character is also found in congregations of former thugs, addicts and drug dealers, thugs, and robbers.

Based on observations made on the Al-Khidmah assembly, the author found several instruments that played an important role in the process of forming the character of the congregation towards ihsan. The following is an explanation of the role of Al-Khidmah in shaping the character of his congregation.

First, the relation model. Ihsan is synonymous with inner experience, so it cannot be studied theoretically because everyone must have different experiences. Therefore, there are at least two ways to know the truth from an experience. This method is to experience it for yourself and through people who have experienced it first. Murshid becomes i'tibar for the congregation as one who reaches ihsan. So in this case the murshid has a very important position as an ihsan person.

The main aspect that should be understood in explaining the relationship between tarekat followers and murshids is their position in the tarekat. Murshid occupies a very important position in the world of pesantren and tarekat. The charisma inherent in him automatically makes him a role model, role model, and leader at the same time.

41 Mukhlasin, Wawancara tentang Majelis dzikir dan Tarekat Al-Khidmah Lampung. 
However, for the tarekat, the murshid's position is the strongest point not only as a leader and guide in the religious aspect, but also as the center of reference for almost all dimensions of the life of tarekat followers. This is indicated by the almost total level of respect and obedience from the congregation to the murshid. ${ }^{42}$

This kind of condition also occurs in the congregation of the AlKhidmah assembly, especially for people with criminal backgrounds who follow Al-Khidmah. The beginning of their participation was not for the purpose of the tarekat, but led to guidance and consultation regarding their life problems. As explained by Abah Mukhlasin (murshid from Al-Khidmah Simbarwaringin):

"In the beginning, they had no goal at all to follow the management of Al-Khidmah. Starting from 2006, one of them (a thug) came to me for treatment. After feeling the healing bit by bit, he immediately invited his friends to come and seek treatment for me. Some of his friends are former robbers, thugs, some are addicts and drug dealers. Not only for treatment, but there are also those who ask for spiritual guidance and talk about life's problems. After a while they were with me and got close emotionally, then I directed them to follow manaqib. ${ }^{43}$

The relationship between the congregation and the murshid does have a difference with the congregation of the tarekat at the pesantren. In general, the relationship between the congregation who comes from the pesantren is in the form of obedience to a teacher who always guides and teaches them. However, in contrast to the people who were specially guided by Abah Mukhlasin, their obedience to the murshid tends to gratitude and a form of trust in someone who has provided solutions to problems.

Apart from the benefit of healing illnesses and spiritual guidance, the more moderate method of the murshid in embracing the congregation is a special attraction for outsiders. Murshid uses the bil mau'izah hasanah (kind advice) method, which is by giving advice to

42 Yusuf, "Tarekat Dan Perubahan Perilaku Sosial Keagamaan Pada Jama'ah Tarekat Qadriyah Wa Naqsabandiyah Di Kota Malang: Perspektif Tindakan Sosial Max Weber," 55.

43 Mukhlasin, Wawancara tentang Majelis dzikir dan Tarekat Al-Khidmah Lampung. 
others which contains instructions of kindness for him. To direct others to goodness, especially congregations who come from criminal backgrounds, Abah Mukhlasin explained as follows:

"So, the approach for other people who are not from the boarding school environment uses a special method. Especially for people who do have a criminal background, namely with mau'izah hasanah (kind advice)/ chatting casually. There is no need to use excessive means and require them to repent immediately. The philosophy is "catching fish without making the water cloudy, the important thing is you can". I guide them slowly, until they change for the better little by little because basically they already know what is good and what is right. So, I just touched his soul with a spiritual method. Talking about change, it can be seen from the aspect of worship". 44

This is the relationship that is formed between the murshid and the congregation of the tarekat. Although using a different approach for each group of people, the substance is to cultivate obedience to a murshid. The relationship between the congregation and the murshid is a manifestation of iltizamut thoat (maintaining obedience) in the form of being obedient to ulil amri.

Second, the rites in the manaqib dzikir. Another aspect that plays a role in shaping the character of the Al-Khidmah congregation is the packaging of dzikir and manaqib in several rites. These rites include the rhythm used in chanting the dzikir sentence. For the Sufis, Islamic notes, such as nasheed or the recitation of sholawat verses, serve to increase the solemnity and preoccupation of presenting Allah SWT. The mind of the Sufi will feel dissolved in these rhythms when doing dzikir or praying. This state produces inner calm and inner calm. The calmness of birth can be seen from fluent and regular recitation of dzikir or shalawat and the position of the body that remains where it is reciting or praying. 45

The ritual is performed using a rhythm in which there is a manaqib recitation. It does not only contain the biography of Sheikh Abdul Qadir al-Jailani r.a., which contains seven chapters, but also prayers. The reading of the manaqib itself uses a unique and distinctive rhythm and song by Al-Khidmah. Prayers offered by the congregation

44 Mukhlasin.

45 Ibrahim Idrus, "Dzikir Nasyid Di Majelis Ta'lim Bani Isma'il Banjarmasin” (Tesis, Banjarmasin, Institut Agama Islam Negeri Antasari, 2015), 1. 
are read simultaneously by the dzikir assembly, namely when moving from chapter one to the next.

When the writer interviewed one of the congregations, he confirmed that he got the calm in the ritual of manaqib from the rhythm and chant. As for the specifics, the appropriate one to calm the heart is when chanting tahlil and wadzifah sentences "ibadallah." The congregation explained in detail as follows.

"Even though in essence this manaqib is a biography of pious people, what is in Al-Khidmah is different. It was clear that when I read the translation of the biography of Shaykh Abdul Qodir Jailani, it did not impress the peace of mind, but in AlKhidmah this is different. Besides it is presumed to be carried out together in a noble assembly. But apart from manaqib, what is no less important is when reading the sentences 'laa ilaha illallah' and 'ibadallah'. When Abah Mukhlasin chanted that sentence, his heart felt calm and focused. Therefore, because of that I also cried. "46

Mahalul qiyam in the manaqib ritual is also a rite which is a practice that leads to the peace of mind of the congregations. Mahalul qiyam is getting up from sitting to stand up when the Prophet's prayer is recited. This rite is a form of respect for the Prophet Muhammad SAW as the most noble servant of Allah.

At that moment, the congregation was in a state of relaxation, their thoughts and feelings and their hearts became focused on one goal, namely presenting Allah SWT. The higher the level of focus and calmness of one's heart, the deeper and longer the duration of one's being in the divine presence. Those who have been consistent in the centering of their souls on Allah will have a kind of inner experience which, according to Abraham Maslow, is described as a transcendent peak experience. ${ }^{47}$ Peak experiences are conditions where the soul experiences peak experiences that provide clear insights into who (whom) they are and their world. This interaction model is an embodiment of one of the principles of khomsa in the form of tashfiyat al-qulub wa tazkiyat al-nafsi (cleansing soul and purifying the heart). Al-Khidmah.

46 Jama'ah Al-Khidmah, Wawancara kepada Jama'ah tentang Dzikir Manaqib 47 Idrus, “Dzikir Nasyid Di Majelis Ta’lim Bani Isma'il Banjarmasin,” 2. 
Third, the interaction model. Jamaah Al-Khidmah has their respective characteristics, social background, region, environment, family, economy, social, political and so on. However, among the congregations, there is an interesting process of interaction. The pattern of interaction built by the Al-Khidmah congregations does not only occur in assemblies, but also applies to the general public.

The interaction media for the Al-Khidmah congregations occurs in the manaqib assembly. Before the manaqib started, the congregations chatted with each other and joked. Usually their conversation is about the events they experience in their daily life. Sometimes their conversations are filled with humor which makes the atmosphere more fluid and increases the intimacy between the congregation. However, the language used is not excessive without saying profanity. After the manaqib is finished, it ends with a meal provided by the host.

Apart from the management assembly, interactions also occur during certain meetings outside the congregation. One of them is when sowan to murshid. Especially for congregants with criminal backgrounds who were coached by Abah Muhlasin, they usually come to talk about the problems they experience in their daily life. For them murshid is not just a tarekat teacher, but also a person who is used as a role model in words and actions. Therefore, what the murshid said and did became an example for them. This pattern of interaction then forms a norm in the form of obedience to the murshid as part of "tarekat adab" which is considered to be related to the spiritual achievements of the congregation.

The interaction action that takes place in Al-Khidmah produces various perceptions. Some perceive it as the experience of joining the tarekat as a process of inner calm. However, there are also those who consider it a social association, namely about how to deal with community conditions and other life problems. In the perspective of the asas al-khomsah, this kind of interaction model is included in the implementation of the principle of khidmah lil ummah (to serve fellow human beings as devotion to Allah SWT). From various forms of interaction that take place between fellow congregation and congregation with murshid then produce output, namely solutions to face life's problems.

\section{Conclusion}

As one of the tarekat forums, Majelis Dzikir Al-Khidmah has succeeded in bringing to life the hadiths about dzikir and ihsan in 
congregations in the middle of a village community that is undergoing transition. The two hadiths live in a tradition that they carry out routinely, both in the form of practice of practice, oral speech, and in writing. The tradition that Majelis al-Khidmah carries out is oriented towards forming the personal of the congregation who is always able to see Allah or at least always remembers (dzikir) that Allah always sees and watches over them. This is the character of ihsan that mentioned The Prophet.

This study is not comprehensive in terms of several aspects. Therefore, for the needs of further studies, various other approaches and methods are needed in assessing the role of dhikir assemblies as a solution to solving problems in the modern era. Then in order to develop broader Islamic studies, it is necessary to conduct research on how the hadiths on dhikir and ihsan are brought to life by other communities and congregations. []

\section{Bibliography}

Adni. "Pola Pembinaan Majelis Taklim Dzikir Nur Al-Mu'min Dalam Pembentukan Karakter Remaja Di Kelurahan Parit Tokaya Kecamatan Pontianak Selatan Kota Pontianak." SOCIOLOGIQUE - Jurnal Sosiologi 3, no. 3 (December 17, 2015). http://fisipuntan.org/jurnal/index.php/sociologique/article/view/124 0 .

Afifah, Nurul. "Salat Duha sebagai Budaya Populer dalam Pemaknaan Anggota Mejelis Dhuha Bantul.” RELIGIA, February 19, 2018, 160-73. https://doi.org/10.28918/religia.v20i2.927.

Ahmadi, Dadi. "Interaksi Simbolik: Suatu Pengantar." Mediator 9, no. 302 (Desember 2008).

Aini, Adrika Fithrotul. "Living Hadis Dalam Tradisi Malam Kamis Majelis Shalawat Diba' Bil-Mustofa." Ar-Raniry: International Journal of Islamic Studies 2, no. 1 (2014).

Anam, Khoirul. "Keluarga Sakinah Dan Dzikir (Studi Atas Peran Majelis Dzikir Al-Khidmah Dalam Pembentukan Keluarga Sakinah Di Kabupaten Semarang)." Skripsi, Institut Agama Islam Negeri Salatiga, 2015.

Asry, M. Yusuf. "Sosialisasi Zikir Melalui Komunikasi dari Mulut ke Mulut dalam Membangun Karakter Masyarakat oleh Majelis Dzikir dan Shalawatan Al Mutathahhirien." WACANA: Jurnal Ilmiah Ilmu Komunikasi 17, no. 1 (July 28, 2018): 125-34. https://doi.org/10.32509/wacana.v17i1.517. 
Blog Author. "Asasul Khomsah MATAN." Religi. MATAN Hadiningrat (blog), 2020. https://matanhadiningrat.com/asasul-khomsah-matan/.

Bukhari, Imam Muhammad bin Ismail al-. Sahih Bukhari. Beirut: Dar Ibn Katsir, 2018.

Dermawan, Moch. Dony. "Sejarah Lahir Dan Berkembangnya Perkumpulan Jama'ah Al-Khidmah Dalam Menyiarkan Ajaran-Ajaran KH. Ahmad Asrori Al-Ishaqy Di Kecamatan Kenjeran Kota Surabaya Pada Tahun 2005-2014." Skripsi, Universitas Islam Negeri Sunan Ampel, 2016.

Faruq, Umar. "Al-Khidmah Kampus UIN Sunan Kalijaga." Skripsi, Universitas Islam Negeri Sunan Kalijaga, 2016.

Fatonah, Dewi. “Tradisi Maulid Arba'in Di Kampung Arab Al-Munawwar Palembang." Jurnal Living Hadis 5, no. 1 (2020).

Hadi, Saiful. Wawancara tentang Sejarah Majelis Dzikir Al-Khidmah Lampung, January 8, 2019.

Hanbal, Imam Ahmad bin. Musnad Imam Ahmad. Bait Afkar Dauliyah, 2000.

Ibnu Majah, Imam. Sunan Ibnu Majah. Bait Afkar Dauliyah, 2006.

Idrus, Ibrahim. "Dzikir Nasyid Di Majelis Ta'lim Bani Isma'il Banjarmasin.” Tesis, Institut Agama Islam Negeri Antasari, 2015.

Jama'ah Al-Khidmah. Wawancara kepada Jama'ah tentang Dzikir Manaqib AlKhidmah, January 30, 2020.

Janah, Lailatul. "Peran Majelis Dzikir Al Khidmah Dalam Mengembangkan Kecerdasan Spiritual (Studi Pada Jamaah Majelis Dzikir Mahasiswa Al Khidmah Kota Salatiga 2016)." PhD Thesis, IAIN SALATIGA, 2017.

Kurniawan, Wahyu, and Rahma Widyana. "Pengaruh Pelatihan Dzikir terhadap Peningkatan Kebermaknaan Hidup pada Mahasiswa." JIP (Jurnal Intervensi Psikologi) 5, no. 2 (December 31, 2013): 217-38. https://doi.org/10.20885/intervensipsikologi.vol5.iss2.art5.

Maarif, Muhammad Anas, and Muhammad Husnur Rofiq. "Dzikir Dan Fikir Sebagai Konsep Pendidikan Karakter: Telaah Pemikiran KH. Munawwar Kholil Al-Jawi." Tadrib 5, no. 1 (2019): 1-20. https://doi.org/10.19109/tadrib.v5i1.3066.

Maturidi, A. "Peranan Majelis Dzikir Dalam Pembentukkan Karakter Remaja." Jurnal Dirosah Islamiyah 1, no. 1 (2019): 79-92. 
Mukhlasin. Wawancara tentang Majelis dzikir dan Tarekat Al-Khidmah Lampung, January 7, 2020.

Muntaha, Ali. “Korelasi Antara Intensitas Mengikuti Majelis Dzikir Khushushy Al-Khotmy Dengan Kontrol Diri (Self Control) Pada Jama'ah Al Khidmah Kabupaten Semarang." Thesis, IAIN Salatiga, 2019. http://erepository.perpus.iainsalatiga.ac.id/5944/.

Naisabury, Imam Muslim bin al-Hajjaj al-Qusyairy an-. Sahih Muslim. Beirut: Dar al-Kitab al-Ilmiyyah, 2010.

Nasai, Imam an-. Sunan An-Nasai. Dar al-Alamiyah li an-Nasyr wa at-Tajlid, 2018.

Nawawi, Imam Abu Zakaria an-. Riyadh As-Shalihin. Al-Maktabah al-Ashriyah, 2010.

Nawawi, Yahya bin Syaraf an-. Al-Arbain an-Nawawi. Damaskus: Dar al-Fath, 2009.

Nuriyatun, Nadzifah. "Implikasi Kegiatan Majelis Al-Khidmah Dalam Membentuk Karakter Toleransi Dan Peduli Sosial Pada Jama'ah Remaja Di Kecamatan Sayung Kabupaten Demak." Thesis, Universitas Wahid Hasyim, 2020. http://eprints.unwahas.ac.id/2539/.

Nurmansyah, Ihsan. "Resepsi Dan Transmisi Pengetahuan Dalam Film Papi Dan Kacung Episode 8-11: Sebuah Kajian Living Hadis.” AL-Quds: Jurnal Studi Al-Qur'an Dan Hadis 3, no. 2 (2019).

Penulis Redaksi Runnews. "Ketahuan Menyembunyikan Sabu, Seorang Pemuda Diamankan Sat Narkoba Polres Lampung Tengah.” News. Runnews Lampung Update (blog), 2019. https://www.runnews.co.id/ketahuan-menyembunyikan-sabuseorang-pemuda-diamankan-sat-narkoba-polres-lampung-tengah/.

Purnomo, Sidik. Trimurjo Dalam Angka (2019). Lampung Tengah: Badan Pusat Statistik Kabupaten Lampung Tengah, 2019.

Qudsy, Saifuddin Zuhri. "LIVING HADIS: GENEALOGI, TEORI, DAN APLIKASI." Jurnal Living Hadis 1, no. 1 (May 6, 2016): 177-96. https://doi.org/10.14421/livinghadis.2016.1073.

Rafi, Muhammad. “Living Hadis: Tradisi Sedekah Nasi Bungkus Hari Jum'at Oleh Komunitas Sijum Amuntai." Jurnal Living Hadis IV, no. 1 (Mei 2019). 
Sari, Ayu Efita. "Pengaruh Pengamalan Dzikir Terhadap Ketenangan Jiwa Di Majlisul Dzakirin Kamulan Durenan Trenggalek." Skripsi, Institut Agama Islam Negeri Tulungagung, 2015.

Siregar, Nina Siti Salmaniah. "Kajian Tentang Interaksionisme Simbolik." Jurnal Ilmu Sosial 4, no. 2 (Oktober 2011).

Supriadi, Yedi. "Dzikir, Spiritualitas Dan Intuisi: Studi Tentang Pembentukan Jati Diri Di Majelis Dzikir Rijalullah Majalengka." Irsyad: Jurnal Bimbingan, Penyuluhan, Konseling, Dan Psikoterapi Islam 8, no. 3 (September 30, 2020): 231-50. https://doi.org/10.15575/irsyad.v8i3.2000.

Tirmidzi, Imam Muhammad bin Isa at-. Sunan Tirmizi. Dar al-Ghad al-Jadid, 2015.

Wibowo, Nur Ikhsan Ari. "Hubungan Keaktifan Mengikuti Majelis Dzikir Dengan Sikap Sabar Jama'ah Al Khidmah Kecamatan Tingkir Kota Salatiga Tahun 2013." Thesis, IAIN SALATIGA, 2013. http://erepository.perpus.iainsalatiga.ac.id/7089/.

Yusuf, Muhammad. "Tarekat Dan Perubahan Perilaku Sosial Keagamaan Pada Jama'ah Tarekat Qadriyah Wa Naqsabandiyah Di Kota Malang: Perspektif Tindakan Sosial Max Weber." Tesis, Universitas Islam Negeri Maulana Malik Ibrahim, 2018. 